\title{
EXPORTS AND THE ECONOMIC PERFORMANCE OF LARGE STATE-OWNED ENTERPRISES IN POLAND: EVIDENCE FROM FIRM-LEVEL DATA*
}

\section{INTRODUCTION}

The aim of this paper is to investigate the relation between exports and economic performance and the extent of state ownership in the largest non-financial enterprises in Poland, included in the ranking Rzeczpospolita Top 2000 Polish Enterprises (henceforth Rzeczpospolita List 2000). Our research is based on firm-level data on export, turnover, employment, productivity, and three financial indicators.

In the last three decades, there has been a significant increase in research on the export determinants of enterprises, which has been driven by at least four key factors. First of all, the liberalization of trade since the 1990s, high economic growth in China, and the enlargement of the European Union have all contributed to a substantial increase in international trade. Companies started to explore new markets and seek opportunities to reap the benefits of exports on firm performance. Secondly, we have observed an increasing share of state-owned enterprises (SOE) in exports and FDI. They have changed their character: from being oriented mostly to the domestic market and having average efficiency, to being active on international markets and having high/ growing efficiency. ${ }^{1}$ Thirdly, a great deal of empirical research has been focused on studying the relationship between internationalization and firm performance, indicating that internationalization leads not only to positive effects but also to costs. It has produced both monotonic and curvilinear findings describing this relation. Finally, due to the higher availability of firm-level data published by some statistical offices, a complex and detailed analysis became possible.

In our research, we focus on the largest Polish state-owned enterprises and provide a full picture of their export activities in 2011-2015 and their economic performance. We refer to the firm-level analysis of exporting compa-

\footnotetext{
* This work was supported by the National Science Centre Poland under Grant number 2015/17/B/HS4/00327, 'Modern state capitalism in Central-East European countries - state-owned enterprises efficiency.'

${ }^{1}$ Cuervo-Cazurra et al. (2014); He, Eden, Hitt (2016); Musacchio et al. (2015); Mariotti, Marzano (2019).
} 
nies, which is quite common in international literature, but in the Polish case it is very modest, mainly due to limited access to such data covering a significant set of companies. On the one hand, they are not made publicly available by the Polish Statistical Office (and if they are, they must be used only in such a way that identification of a single company is impossible), on the other hand, companies very rarely share such data in their financial reports. Moreover, we analyse not only the majority state-owned enterprises but also those companies with a minority but controlling stake held by the state (the Polish Statistical Office only defines an SOE as an entity in which the state holds an ownership stake of more than 50.01\%).

We address the following research questions:

1. What is the share of export companies in the group of the largest non-financial enterprises in Poland, according to ownership structure (state-owned and privately-owned companies) and sectors?

2. Are there differences in the economic performance of exporting companies compared to their non-exporting counterparts?

To assess the economic performance of companies, we used descriptive statistics as well as the Mann-Whitney $\mathrm{U}$ and the ANOVA tests, and the logit model.

We contribute to the literature by analysing and comparing a wide set of variables describing the economic performance of the largest Polish companies using firm-level data with a detailed distinction between state-owned (majority and minority) and privately-owned companies. We have found that among the largest exporters, state-owned companies and companies from the manufacturing and mining sectors still dominate. Having compared economic performance, we have found that exporting companies enjoy higher returns on sales and returns on assets than non-exporting companies, and exporting private companies have higher efficiency of property management (based on ROA and ROE) than their state-owned counterparts.

The paper is structured as follows. Section 2 reviews the literature on the relation between exports and economic performance. Section 3 introduces a statistical description of the largest Polish state-owned exporters in the period 2011-2015. Section 4 presents the results of the empirical analysis and comparisons of exporters and non-exporters in terms of ownership structure and business sectors. Section 5 concludes this research.

\section{EXPORTS AND ECONOMIC PERFORMANCE - LITERATURE REVIEW}

Exports are a traditional form of international expansion for companies that takes advantage of high elasticity due to relatively easy adjustments and low capital expenditures. The determinants of exports and imports are mainly explained in the theories of international trade, according to which companies' drive to trade is motivated by profits. Their microeconomic motivation is not 
discussed. As Gorynia ${ }^{2}$ outlines, there is no complete and coherent theory of the international activities of companies that combines not only international trade theories but also theories of firms, FDI, competition or branches, though some combined theories can be observed in the so-called integrated models of trade and international production. ${ }^{3}$

The economic performance of exporters is analysed in two key dimensions: productivity and financial performance. The former is measured by labour productivity (total sales per employee) and is used mainly to explain drivers of exports, while the latter is measured by various financial indicators and is applied to provide a broader picture of a company's profitability, and to analyse the results of internationalization. Microeconometric analysis is applied in both dimensions, though studies (particularly in the second dimension) are still quite limited due to the lack of comprehensive data on the firm-level. In research, economic results and activities are compared between two groups: exporting and non-exporting companies.

The exports of firms are explained by the 'New' New Trade Theory. ${ }^{4}$ Theoretical models show that firms below a certain cut-off point in productivity operate only in a national market, while firms above it decide to internationalize. This decision is determined by the fixed export costs which need to be met (for instance the costs of learning about a foreign market, setting up a distribution network, adopting products to tastes and the technical standards of foreign consumers). Only more productive companies can afford to do this. According to many empirical studies, exporting firms are more productive than non-exporters. ${ }^{5}$ Export activity depends on productivity, but it the relation also works the other way, meaning that productivity depends on export. In the second case, exporting companies become more productive due to the process of learning-by-exporting. ${ }^{6}$ According to learning-by-exporting hypothesis, contacts with international buyers and competitors produce learning effects for exporters. International competition forces companies to be more efficient reducing so-called 'X-inefficiency' ${ }^{7}$ - and stimulates innovation. ${ }^{8}$ However exports themselves do not lead to a profitability advantage for exporting companies compared to non-exporting ones. These advantages are related to the conditions under which exports could occur, such as export intensity and regularity, the type of business activity or conducting research and development. Cassiman and Golovko ${ }^{9}$ did not find any differences in productivity between exporters and non-exporters when only taking innovative activities into con-

2 Gorynia (2007): 23-29.

3 Mińska-Struzik (2006): 60-79.

${ }^{4}$ Helpman (2006); Melitz (2003).

${ }^{5}$ See, for example, Powell, Wagner (2014); Wagner (2007); Delgado, Farinas, Ruano (2002); Girma, Greenaway, Kneller (2002); Aw, Chen, Roberts (2001).

${ }^{6}$ Mińska-Struzik (2014) provides a very detailed overview of empirical studies on learning-by -exporting.

7 Andersson, Lööf (2009).

8 Greenaway, Kneller (2007); Wagner (2007); (2012).

9 Cassiman, Golovko (2007). 
sideration. Cieślik and Michałek ${ }^{10}$ indicate that the probability of exporting is positively related to both product and process innovations. In the case of Polish exporting companies, many authors ${ }^{11}$ confirm a positive relation between a firm's productivity and the probability of export activity. The larger the company, the higher the probability of exports. Moreover, companies with foreign capital are more export-oriented.

The effects of internationalization on economic performance (on the level of countries, industries, companies) are presented in many empirical studies. ${ }^{12}$ However, the results of these studies are ambiguous. The relations between internalization and economic performance are indicated to be either positive or negative. One of the reasons for this ambiguity could be an empirical problem of how to define and operationalize levels of internationalization. For instance, it could be defined as a share of export in total sales, or by referring to the classic path of internalization from exports to FDI. Most studies confirm the relation between profitability and internationalization, which depends on the degree of internationalization. It could be described with a U-shaped curve. ${ }^{13}$ According to this model, in the first stage of internationalization a firm's economic performance deteriorates, which could be connected with high costs and insufficient experience in international transactions. Subsequently, profitability increases, which could be caused by the positive effects of learning-by-exporting. The non-linear relations between the two variables could also be presented as J-shaped curves, S-shaped curves, or their reverse versions. A reversed S-shaped curve means that in the early stage of internationalization economic performance improves, subsequently deteriorates, and finally it starts to improve in the last stages. According to Bausch and Krist,${ }^{14}$ this relation is not universal, but it is rather context-related and depends on the environment of any given company.

Benito et al. ${ }^{15}$ analysed the relationship between state ownership and internationalization in Norwegian companies. They argued that state ownership does not decrease the ability to benefit from internationalization. There is even evidence that the opposite happens: potential benefits such as learning-by-exporting and reducing X-inefficiency are even greater in SOEs, and this may help reduce any gap between them and private-owned companies. Elliott and Zhao ${ }^{16}$ show that in China, although foreign-owned companies are more productive than non-exporting companies, exporting SOEs are the most productive of all groups of companies. They explain this by the substantial levels of support that the Chinese government offers to national champions

10 Cieślik, Michałek (2017).

11 Brodzicki, Ciołek (2016); Cieślik, Michałek, Michałek (2012); Kolasa, Hagemejer (2008); Hegemejer (2006).

12 See Tallman, Li (1996); Riahi-Belkaoui (1998); Ruigrok, Wagner (2003); Capar, Kotabe (2003); Chen, Hsu (2010); Contractor et al. (2007); Ramsey et al. (2012); Singla, George (2013).

13 See Ruigrok, Wagner (2003) for large German companies; Doryń, Stachyra (2008) for Polish companies.

14 Bausch, Krist (2007).

15 Benito et al. (2016).

16 Elliott, Zhao (2016). 
via grants for research and development, preferential import regulations and priority loan approvals.

Based on the literature we formulated one hypothesis:

H1: Exporters have better economic performance than non-exporters irrespective of ownership structure and business sectors.

We analyse the relations between exports and economic performance in two dimensions: productivity and financial indicators. Our research was conducted on the basis of firm-level data and concerns the largest non-financial Polish companies according to ownership structure and business sectors.

\section{DESCRIPTION OF THE LARGEST STATE-OWNED POLISH EXPORTERS}

We analysed the scale of exports of the 2,000 largest non-financial Polish enterprises using data published by the newspaper Rzeczpospolita in 20112015. ${ }^{17}$ We excluded 31 municipal enterprises and 122 subsidiaries. ${ }^{18}$ In total, we used the firm-level data of the $1,846^{19}$ largest Polish companies in 20112015. The raw data comprise: turnover (without excise), profit, total assets, equity, employment, exports. To tackle the missing data problem ${ }^{20}$ we used statistical methods such as extrapolation and arithmetic mean to estimate the missing values (they concerned turnover and employment ${ }^{21}$ ). We computed firms' productivity (turnover per employee) and three financial indicators of profitability: ROA (return on assets), ROE (return on equity) and ROS (return on sales).

Since our research is mainly motivated by links between exports and state ownership, we had to introduce some key definitions. We needed to

17 Data on exports at the firm-level are not available. Commercial databases such as Amadeus van Dijk do not cover them. The Polish National Statistical Office (GUS) does not publish them due to statistical confidentiality. Hagemejer and Kolasa (2006 and 2008) obtained these data from GUS, however, they used them in such a way that identification of a single company was impossible. In our research, we focus on state and private companies. Since the sample of SOEs is rather small, therefore, it is impossible to maintain complete anonymity. Bearing that in mind, the only source of data seems to be the Rzeczpospolita List 2000, which is commonly regarded as reliable. The list is based on information voluntarily sent in by companies. However, one limitation is that some companies may decide not to share detailed information. During our research, we faced a serious problem of missing data on exports (mostly in the case of private companies) because many companies did not reveal them, which is probably caused by the fact that this information is sensitive due to company competitiveness.

18 In the cases when information for a capital group was limited, we excluded such a capital group and included its subsidiaries (e.g. Polska Grupa Zbrojeniowa).

19 Additionally, we excluded Naukowa i Akademicka Sieć Komputerowa SA, Warszawa since it is a national research center.

${ }^{20}$ If the missing observation at time $t$ is surrounded by available observations, the arithmetic mean is inserted. When data are not available for the subsequent years, forward extrapolation is used. When data are not available for the preceding years, backward extrapolation is used.

21 Before estimation, employment data were supplemented with data available in the Amadeus database. 
identify exporting companies, and this we did in two stages. Firstly, based on the Rzeczpospolita List 2000, we classified a company as an exporting one when it had been involved in exports for at least two out of the last three years, or three out of the five years covered by the Rzeczpospolita List 2000 (535). Companies which exported only during one or two out of the 5 years were regarded as unclassified (107). Secondly, based on the websites and official reports of companies and also other databases, we once again verified all the unclassified and non-exporting companies from the Rzeczpospolita List 2000. According to our search, 669 additional companies were categorized as exporters. Finally, there were 1,204 exporters identified among the 2,000 largest companies.

Ownership structure is discussed in terms of whether the main stakeholder is a state or private. A state-owned enterprise (SOE) is defined as an entity in which the state holds directly or indirectly an ownership stake of more than $50.01 \%$, or when a state share is between $25.01 \%$ and $50.00 \%$ and a state is a largest shareholder within the dispersed ownership structure..$^{22}$ In order to indicate the ownership status of the enterprises, ownership structures were checked using the Amadeus database published by Bureau van Dijk, EMIS and EIKON Thomson Reuters databases and official company reports. ${ }^{23}$

Among 1,846 analysed companies (Table 1), there were 1,204 exporters (a share of $65.2 \%$ ), and $97.4 \%$ of them were privately-owned $(\mathrm{N}=1,173)$, while only $2.6 \%$ were state-owned $(\mathrm{N}=31)$.

Table 1

Description of research sample $(\mathrm{N}=1,846)$

\begin{tabular}{|c|c|c|c|c|c|c|c|c|}
\hline \multirow{2}{*}{\multicolumn{2}{|c|}{ Number of companies }} & \multirow{3}{*}{$\begin{array}{c}\% \\
100.0\end{array}$} & \multicolumn{6}{|c|}{ Section - number } \\
\hline & & & \multirow{2}{*}{$\frac{\mathbf{C}}{762}$} & \multirow{2}{*}{$\begin{array}{c}\mathbf{F} \\
122\end{array}$} & \multirow{2}{*}{$\begin{array}{c}\mathbf{G} \\
590\end{array}$} & \multirow{2}{*}{$\begin{array}{c}\mathbf{H} \\
93\end{array}$} & \multirow{2}{*}{$\begin{array}{c}\mathbf{J} \\
71\end{array}$} & \multirow{2}{*}{$\begin{array}{c}\text { others } \\
208\end{array}$} \\
\hline Total & 1,846 & & & & & & & \\
\hline of which: SOEs & 44 & 2.4 & 12 & 3 & 3 & 8 & 1 & 17 \\
\hline of which: exporters & 1,204 & 65.2 & 701 & 35 & 300 & 64 & 34 & 70 \\
\hline of which: SOEs & 31 & 1.7 & 11 & 2 & 2 & 3 & 0 & 13 \\
\hline $\begin{array}{l}\text { of which: } \\
\text { non-exporters }\end{array}$ & 642 & 34.8 & 61 & 87 & 290 & 29 & 37 & 138 \\
\hline of which: SOEs & 13 & 0.7 & 1 & 1 & 1 & 5 & 1 & 4 \\
\hline
\end{tabular}

Notes: C - manufacturing; F - construction; G - wholesale and retail trade; repair of motor vehicles including motorcycles; $\mathrm{H}$ - transportation and storage; $\mathrm{J}$ - information and communication.

Source: the authors' own elaboration based on the Rzeczpospolita List 2000.

${ }^{22}$ See Bałtowski, Kozarzewski (2016); Szarzec, Nowara (2017).

${ }^{23}$ In such cases where the data on the ownership structure differed between sources, the official reports were decisive. 
According to the sections of Polish Classification of Activities (PKD), exporting companies dominate in section $\mathrm{C}$ (Manufacturing) and section $\mathrm{G}$ (Wholesale and retail trade; repair of motor vehicles and motorcycles), respectively, $58.2 \%$ and $24.9 \%$ out of the largest companies. $92.0 \%$ of manufacturing companies are exporters while $68.8 \%$ of companies from section $\mathrm{H}$ export their products. Section C, due to the largest number of exporters in general and the share of exporters in the section, will also be shown in further analyses.

Taking into account ownership structure, there were 31 exporting SOEs out of 44 SOEs (a share of 70.5\%). 65.1\% private companies are exporters. Hagemejer ${ }^{24}$ confirmed that Polish SOEs export more often than private companies, which could be explained by their longer experience and presence in the market. It is consistent with the conclusion that a longer period of activity of a company on international markets is followed by higher international experience and level of internationalization. However, relations between time and international experience (meaning the level of internationalization) have

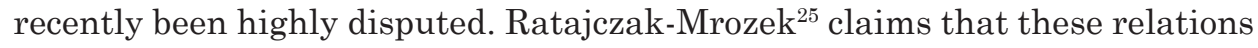
are complex and non-linear.

As we mentioned before, our dataset does not include data about volumes of export for all the identified largest exporting companies. In total, we have export data for 559 companies (for different years) (Table 2). Based on this, we calculated a propensity to export, defined as a share of export in total turnover (without excise) of a company. An average share was 19.0\%-23.6\% for SOEs while it was $36.7 \%-39.8 \%$ for private companies. A lower propensity for SOEs to export is consistent with the observations made by Estrin et al. ${ }^{26}$, which confirmed (based on an analysis of 3,087 companies from 47 countries) that state ownership reduces a firm's degree of internationalization due to exports. However, they added that this effect depends on the political and institutional factors of the home country of any given company.

Table 2

Average share of exports in total turnover, in \%

\begin{tabular}{|l|r|r|r|r|r|}
\hline \multicolumn{1}{|c|}{ Companies } & $\mathbf{2 0 1 1}$ & $\mathbf{2 0 1 2}$ & $\mathbf{2 0 1 3}$ & $\mathbf{2 0 1 4}$ & $\mathbf{2 0 1 5}$ \\
\hline State-owned enterprises & 23.5 & 19.0 & 20.8 & 23.5 & 23.6 \\
\hline (the number of enterprises) & 28 & 28 & 27 & 27 & 25 \\
\hline Private enterprises & 36.7 & 38.0 & 38.3 & 39.8 & 39.7 \\
\hline (the number of enterprises) & 477 & 489 & 532 & 526 & 493 \\
\hline Section C & 45.9 & 47.6 & 47.9 & 48.9 & 48.6 \\
\hline Total & 280 & 284 & 304 & 307 & 289 \\
\hline (the number of enterprises) &
\end{tabular}

Source: the authors' own elaboration based on the Rzeczpospolita List 2000.

${ }^{24}$ Hagemejer (2006): 42.

25 Ratajczak-Mrozek (2015).

26 Estrin et al. (2016). 
Some information on the ownership structure of exports is revealed in the case when the analysis covers only the largest and most significant Polish enterprises included in Rzeczpospolita List 2000. We analysed the scale of SOEs in exports using the top 25 and top 50 exporters according to the average annual export revenues in 2013-2015 (these companies are also the largest in terms of their turnover). We ranked them according to their annual exports and considered only companies which revealed exports in at least two years in the period of 2013-2015 (486 companies). As a result, among the top 25 exporters, 6 SOEs were identified, all of them having their origins in the socialist period. They have as much as a $55 \%$ share in the total average export in 2013-2015, mainly due to one company - PKN Orlen, a conglomerate from the oil industry. Among the top 25 exporting enterprises, most SOEs operated in the following sectors: C, B and D. The majority of private exporting companies operate in the manufacturing sector, mostly in the manufacture of motor vehicles. In comparison to the top 25, among the top 50 exporting companies there is only one more SOE. The share of 7 exporting SOEs in the top 50 is $46 \%$.

Table 3

State enterprises in the set of largest Polish exporters (according to average exports in 2013-2015)

\begin{tabular}{|l|c|c|c|c|}
\hline $\begin{array}{c}\text { Largest } \\
\text { exporters }\end{array}$ & $\begin{array}{c}\text { Number of } \\
\text { enterprises }\end{array}$ & $\begin{array}{c}\text { Turnover } \\
\text { in PLN millions }\end{array}$ & $\begin{array}{c}\text { Export } \\
\text { in PLN millions }\end{array}$ & Employment \\
\hline TOP 25 total & 25 & $307,655.6$ & $183,357.0$ & 212,922 \\
\hline $\begin{array}{l}\text { State-owned } \\
\text { enterprises }\end{array}$ & 6 & $205,634.4$ & $101,397.4$ & 134,072 \\
\hline TOP 50 total & 50 & $386,950.0$ & $224,602.6$ & 301,105 \\
\hline State-owned & 7 & $209,099.7$ & $103,586.1$ & 136,218 \\
enterprises & & $54.0 \%$ & $46.1 \%$ & $45.2 \%$ \\
\hline
\end{tabular}

Source: the authors' own elaboration based on the Rzeczpospolita List 2000.

The largest Polish exporting companies are the state-owned PKN Orlen and KGHM Polska Miedź, while the third company is a private firm - FCA Poland (the former two reported average exports of PLN64.1 bn for the years 2013-2015, and the third one exports of PLN11.8 bn). The first two companies have the largest share in total exports (PKN Orlen - 35.1\% and KGHM - 9.1\% among the top 25 exporters). They are regarded as multinational companies ${ }^{27}$. Also, Lotos and PGNiG are multinationals. Azoty, PKP and Tauron have FDI, although their involvement abroad is not so high. There are substantial

${ }^{27}$ In 2015, 7 out of the 36 main entities of PKN Orlen were located abroad, in six countries, and the company was involved in 15 acquisitions or minority stake purchase transactions. KGHM was the owner of nine foreign subsidiaries supervised directly and 26 foreign affiliates. (Götz, Jankowska 2018: 9-11.) 


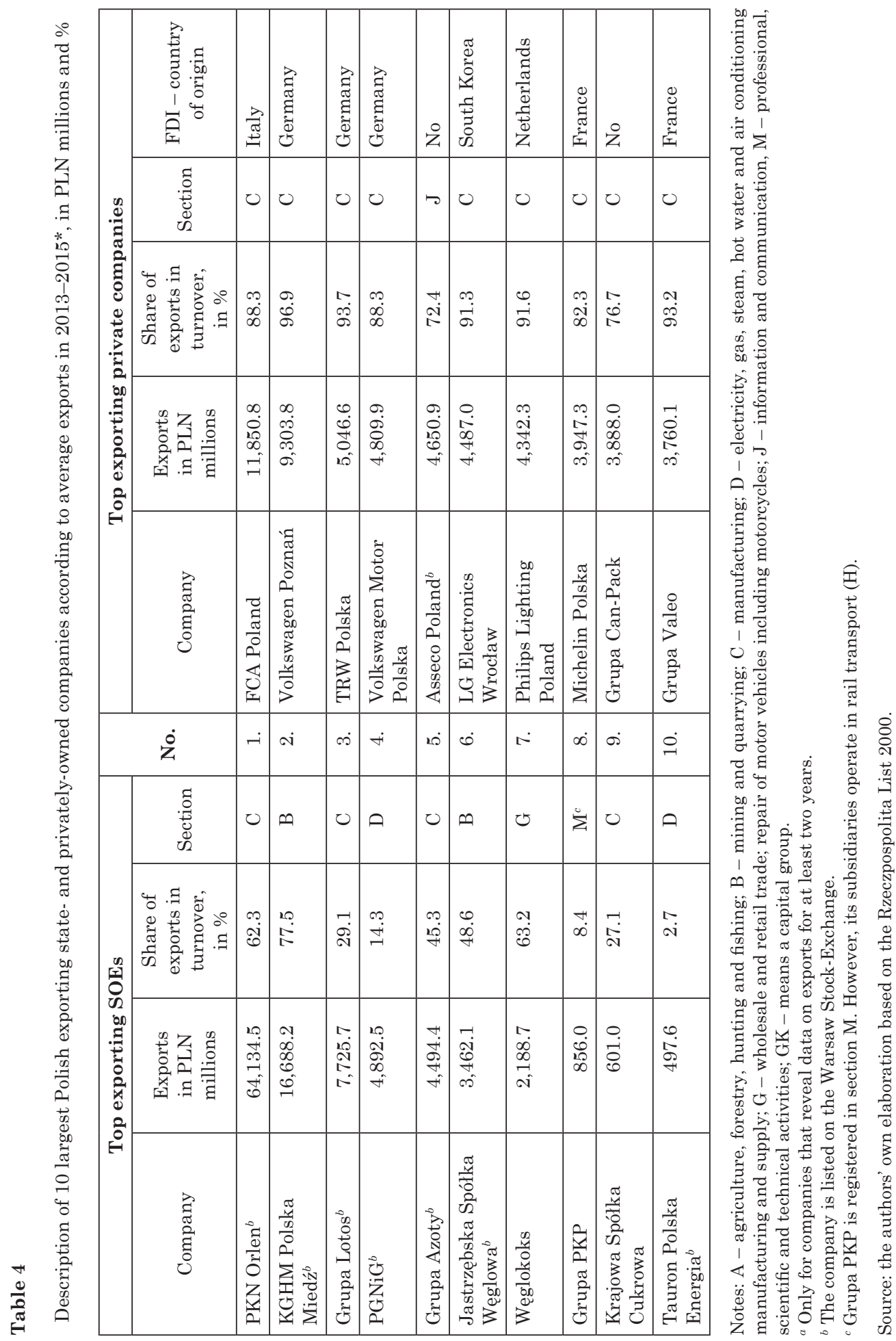


differences in shares of exports in the total turnover between SOEs and private companies in the top 10 exporting companies. In the case of only three SOEs, this share exceeds $60 \%$, while in the case of all private companies this share exceeds $70 \%$; and 8 out of 10 of the largest private exporters are FDIs, mostly from Germany. Only the two largest private exporting companies are of Polish origin. This information on foreign subsidiaries confirms the conclusions of the new trade theory that companies with foreign capital are more inclined to export.

\section{AN EMPIRICAL ANALYSIS OF EXPORTERS AND NON-EXPORTERS IN TERMS OF OWNERSHIP STRUCTURE AND BUSINESS SECTORS}

To analyse the relationships between exports and the economic performance of Polish companies, we compared differences between the averages of their economic indicators among groups of companies. We considered two dimensions of performance: productivity and 3 financial indicators related to profit (ROA, ROE and ROS). Because of the incomplete data, we decided to calculate the averages of the abovementioned indicators for three years in the period of 2013-2015 (an average was calculated only if at least two observations were available). This procedure facilitated the inclusion of more enterprises in our analysis than if we had considered only enterprises with complete observations for each year. The computed averages were quite varied, which could have been caused by the fact that our sample covered companies from various sections. Therefore, to avoid the impact of outliers in the econometric estimation, we applied a trimmed mean (truncated mean). This is a statistical measure of a central tendency which is robust to the presence and potential impact of outliers in a sample. We excluded from our analysis all outstanding observations with values exceeding the mean of three standard deviations. ${ }^{28}$ The maximum and minimum values of each financial indicator were set at the level of the 90th and 10th percentile respectively.

We analysed the differences within the following six groups: (1) total exporters and total non-exporters; (2) state-owned exporters and state-owned non-exporters; (3) private exporters and private non-exporters; (4) exporters and non-exporters from the manufacturing section; (5) state-owned exporters and private exporters; (6) state-owned non-exporters and private non-exporters. In order to analyse the differences among the groups, we applied the ANOVA test and the Mann-Whitney U test. The former is a parametric test that assumes that the analysed data are normally distributed while the latter is a non-parametric test that checks the differences in medians caused by one factor. ${ }^{29}$ We applied this procedure to all cases.

\footnotetext{
${ }^{28}$ Rothenberg et al. (1966).

${ }^{29}$ Aczel (2000).
} 
Firstly, we focused on a productivity measure. It is expressed as the ratio of output to inputs used in a production process in any given period. It could be measured in various ways, for example, total factor productivity (TFP) or value added per 1 employee. Due to the availability of data in our research, we employed the value of turnover per 1 employee as a productivity measure. ${ }^{30}$ We computed it as an average in the years 2013-2015. As we mentioned in the previous section, there are two interpretations of the relationships between exports and productivity. On the one hand, exports depend on productivity, but on the other hand, it works the other way, meaning that productivity depends on exports. In the second case, exporting companies become more productive due to the process of learning-by-exporting.

We formulated and tested the following hypothesis: exporters have higher productivity than non-exporters irrespective of their ownership structure and business sectors.

Table 5

Productivity (turnover per 1 employee), in PLN thousands

\begin{tabular}{|c|c|c|c|c|c|c|}
\hline Companies & $\begin{array}{c}\text { Exporter/ } \\
\text { non-exporter }\end{array}$ & $\begin{array}{c}\text { Average } \\
2013-2015\end{array}$ & $\mathbf{N}$ & $\begin{array}{l}\text { Standard } \\
\text { deviation }\end{array}$ & ANOVA $^{a}$ & $\begin{array}{c}\text { Mann- } \\
\text {-Whitney } \mathbf{U}^{a}\end{array}$ \\
\hline \multirow[t]{2}{*}{ Total } & exporter & $2,234.15$ & 799 & $5,752.92$ & \multirow{2}{*}{$\mathrm{Y}$} & \multirow{2}{*}{$\mathrm{Y}$} \\
\hline & non-exporter & $3,940.28$ & 295 & $10,206.96$ & & \\
\hline \multirow[t]{2}{*}{ State-owned } & exporter & $1,298.43$ & 29 & $1,570.04$ & \multirow{2}{*}{$\mathrm{N}$} & \multirow{2}{*}{$\mathrm{N}$} \\
\hline & non-exporter & 912.21 & 9 & $1,071.16$ & & \\
\hline \multirow{2}{*}{$\begin{array}{l}\text { Privately- } \\
\text {-owned }\end{array}$} & exporter & $2,269.39$ & 770 & $5,849.81$ & \multirow{2}{*}{$\mathrm{Y}$} & \multirow{2}{*}{$\mathrm{Y}$} \\
\hline & non-exporter & $4,035.57$ & 286 & $10,350.90$ & & \\
\hline \multirow{2}{*}{$\begin{array}{l}\text { Section } \mathrm{C}- \\
\text { manufacturing }\end{array}$} & exporter & $1,230.90$ & 434 & $2,269.64$ & \multirow{2}{*}{$\mathrm{N}$} & \multirow{2}{*}{$\mathrm{N}$} \\
\hline & non-exporter & $1,822.75$ & 31 & $3,138.97$ & & \\
\hline
\end{tabular}

${ }^{a}$ Significance level of 0.05. Y - significant, N - not significant. N denotes the number of observations. A group of state-owned companies consists of both majority and minority state-owned enterprises.

Source: the authors' own elaboration with SPSS based on the data from the Rzeczpospolita List 2000.

The hypothesis of the higher productivity of exporters than non-exporters was falsified in three groups: total companies, section $\mathrm{C}$ and private companies. Non-exporting companies have higher average productivity than exporting companies (in the case of total companies, the average productivity among non-exporters is higher by about $76 \%$ than among exporters). In the cases of total companies and private companies, the differences in average productivity between non-exporters and exporters are statistically significant according to the ANOVA test. These results are also confirmed by the Mann-Whitney $\mathrm{U}$ test. The results are not consistent with the literature, which could have

30 Similarly to Cieślik, Michałek, Michałek (2012). 
been caused by at least two factors. Firstly, our sample covers only large companies. According to the National Statistical Office of Poland (GUS 2016, Table 3), in 2015 the average turnover per 1 employee was PLN610.34 thousand while in the group of companies with employment of over 250 people it was PLN657.96 thousand. In our analysis, the average turnover per 1 employee was PLN2,694.21 thousand which was 4 times higher than according to GUS. Histograms of exporters and non-exporters for the Rzeczpospolita List 2000 do not have normal distribution. Secondly, we faced a missing data problem, in particular in the case of employment data (data for only $66 \%$ of exporters and $46 \%$ of non-exporters were available), therefore, our results could be biased.

According to the data, exporting SOEs experienced higher productivity than non-exporting SOEs. However, neither the ANOVA nor the Mann-Whitney $U$ tests confirmed significant differences between these two groups. Additionally, we checked whether there are differences in average productivity between groups of state and private exporters, and between state and private non-exporters. In the former case, the results were not significant, while in the latter they were ambiguous (Table 6).

Table 6

ANOVA and Mann-Whitney U test of average productivity in 2013-2015

\begin{tabular}{|c|c|c|c|}
\hline Companies & Owner & ANOVA $^{a}$ & Mann-Whitney $\mathbf{U}^{a}$ \\
\hline \multirow{2}{*}{ Exporters } & state-owned & \multirow{2}{*}{$\mathrm{N}$} & \multirow{2}{*}{$\mathrm{N}$} \\
\hline & privately-owned & & \\
\hline \multirow[t]{2}{*}{ Non-exporters } & state-owned & \multirow{2}{*}{$\mathrm{N}$} & \multirow{2}{*}{$\mathrm{Y}$} \\
\hline & privately-owned & & \\
\hline
\end{tabular}

${ }^{a}$ Significance level of 0.05. Y - significant, N-not significant.

Secondly, we analysed economic performance as measured by three financial indicators related to profit: ROA, ROE and ROS. We tested the following hypothesis: exporting companies have better economic performance than non-exporting companies. The computed averages of all financial indicators in 2013-2015 show that exporters have higher financial performance than non-exporters. According to the ANOVA test, the differences between these groups are statistically insignificant. However, the Mann-Whitney U test confirmed that there was a statistically significant difference between the groups in the cases of ROA and ROS.

Very similar averages of indicators and test results were produced when comparing private exporters with non-exporters. This is caused by the fact that private companies make up more than $97.6 \%$ of the total sample.

Taking into consideration SOEs, non-exporting SOEs performed better (ROA, ROE and ROS) than exporting ones, which was contrary to the hypothesis. However, the tests did not confirm that the differences were statistically significant. 
Statistically significant differences occurred in the case of manufacturing (section C) exporters and non-exporters (positive results of both tests). Exporting companies have values of ROA and ROS about 30\% higher than their non-exporting counterparts.

Table 7

ROA, ROE and ROS

\begin{tabular}{|c|c|c|c|c|c|c|}
\hline $\begin{array}{l}\text { Compa- } \\
\text { nies }\end{array}$ & $\begin{array}{c}\text { Exporter/ } \\
\text { non-exporter }\end{array}$ & $\begin{array}{c}\text { Average } \\
2013- \\
2015\end{array}$ & $\mathbf{N}$ & $\begin{array}{l}\text { Standard } \\
\text { deviation }\end{array}$ & $\mathbf{A N O V A}^{a}$ & $\begin{array}{c}\text { Mann- } \\
\text {-Whitney } \\
\text { U* }\end{array}$ \\
\hline \multicolumn{7}{|c|}{ ROA } \\
\hline \multirow[t]{2}{*}{ Total } & exporter & 8.88 & 1,098 & 8.28 & $\mathrm{~N}$ & $\mathrm{Y}$ \\
\hline & non-exporter & 8.33 & 585 & 14.23 & & \\
\hline \multirow{2}{*}{$\begin{array}{l}\text { State-ow- } \\
\text { ned }\end{array}$} & exporter & 4.55 & 29 & 6.07 & $\mathrm{~N}$ & $\mathrm{~N}$ \\
\hline & non-exporter & 5.23 & 11 & 9.18 & & \\
\hline \multirow{2}{*}{$\begin{array}{l}\text { Privately- } \\
\text {-owned }\end{array}$} & exporter & 8.99 & 1,069 & 8.31 & $\mathrm{~N}$ & $\mathrm{Y}$ \\
\hline & non-exporter & 8.39 & 574 & 14.31 & & \\
\hline \multirow{2}{*}{$\begin{array}{l}\text { Section C - } \\
\text { manufac- } \\
\text { turing }\end{array}$} & exporter & 9.09 & 650 & 7.22 & $\mathrm{Y}$ & $\mathrm{Y}$ \\
\hline & non-exporter & 6.78 & 59 & 8.09 & & \\
\hline \multicolumn{7}{|c|}{ ROE } \\
\hline \multirow[t]{2}{*}{ Total } & exporter & 19.88 & 1,099 & 61.36 & $\mathrm{~N}$ & $\mathrm{~N}$ \\
\hline & non-exporter & 15.19 & 586 & 185.69 & & \\
\hline \multirow{2}{*}{$\begin{array}{l}\text { State- } \\
\text {-owned }\end{array}$} & exporter & 5.78 & 29 & 15.62 & $\mathrm{~N}$ & $\mathrm{~N}$ \\
\hline & non-exporter & 12.09 & 11 & 14.55 & & \\
\hline \multirow{2}{*}{$\begin{array}{l}\text { Privately- } \\
\text {-owned }\end{array}$} & exporter & 20.26 & 1,070 & 62.09 & $\mathrm{~N}$ & $\mathrm{~N}$ \\
\hline & non-exporter & 15.25 & 575 & 187.45 & & \\
\hline \multirow{2}{*}{$\begin{array}{l}\text { Section C- } \\
\text { manufac- } \\
\text { turing }\end{array}$} & exporter & 16.93 & 651 & 65.86 & $\mathrm{~N}$ & $\mathrm{~N}$ \\
\hline & non-exporter & 9.89 & 59 & 49.19 & & \\
\hline \multicolumn{7}{|c|}{ ROS } \\
\hline \multirow[t]{2}{*}{ Total } & exporter & 5.58 & 1,103 & 6.56 & $\mathrm{~N}$ & $\mathrm{Y}$ \\
\hline & non-exporter & 5.52 & 587 & 12.41 & & \\
\hline \multirow{2}{*}{$\begin{array}{l}\text { State- } \\
\text {-owned }\end{array}$} & exporter & 8.29 & 29 & 12.69 & $\mathrm{~N}$ & $\mathrm{~N}$ \\
\hline & non-exporter & 9.16 & 11 & 9.82 & & \\
\hline \multirow{2}{*}{$\begin{array}{l}\text { Privately- } \\
\text {-owned }\end{array}$} & exporter & 5.51 & 1,074 & 6.30 & $\mathrm{~N}$ & $\mathrm{Y}$ \\
\hline & non-exporter & 5.45 & 576 & 12.45 & & \\
\hline \multirow{2}{*}{$\begin{array}{l}\text { Section C- } \\
\text { manufac- } \\
\text { turing }\end{array}$} & exporter & 6.27 & 652 & 6.10 & $\mathrm{Y}$ & $\mathrm{Y}$ \\
\hline & non-exporter & 4.56 & 59 & 8.54 & & \\
\hline
\end{tabular}

${ }^{a}$ Significance level of 0.05. Y - significant, N - not significant. 
When comparing financial indicators of companies in terms of their ownership structure, we found that private companies performed better in the case of ROA and ROE than SOEs, while SOEs experienced higher ROS. It could be inferred that private companies have a higher efficiency of property management.

We also analysed the differences in two groups: between private and state-owned exporters and private and state-owned non-exporters. According to the ANOVA test, in the first group there were significant differences in ROA and ROS. In the second group, there were no significant differences. The Mann-Whitney $U$ test showed that there were differences in ROA and ROE in both groups. Since the Mann-Whitney $U$ test is a non-parametric test and has lower power in comparison to ANOVA, the results based on the first test should be interpreted with caution.

Table 8

ANOVA of average of ROA, ROE and ROS in 2013-2015

\begin{tabular}{|c|c|c|c|c|c|c|c|}
\hline \multirow{2}{*}{ Companies } & \multirow{2}{*}{ Owner } & \multicolumn{3}{|c|}{ ANOVA $^{a}$} & \multicolumn{3}{|c|}{ Mann-Whitney $\mathbf{U}^{a}$} \\
\hline & & $\mathrm{ROA}$ & ROE & ROS & $\mathrm{ROA}$ & ROE & ROS \\
\hline \multirow[t]{2}{*}{ Exporters } & state-owned & \multirow{2}{*}{$\mathrm{Y}$} & \multirow{2}{*}{$\mathrm{N}$} & \multirow{2}{*}{$\mathrm{Y}$} & \multirow{2}{*}{$\mathrm{Y}$} & \multirow{2}{*}{$\mathrm{N}$} & \multirow{2}{*}{$\mathrm{Y}$} \\
\hline & privately-owned & & & & & & \\
\hline \multirow[t]{2}{*}{ Non-exporters } & state-owned & \multirow{2}{*}{$\mathrm{N}$} & \multirow{2}{*}{$\mathrm{N}$} & \multirow{2}{*}{$\mathrm{N}$} & \multirow{2}{*}{$\mathrm{Y}$} & \multirow{2}{*}{$\mathrm{Y}$} & \multirow{2}{*}{$\mathrm{N}$} \\
\hline & privately-owned & & & & & & \\
\hline
\end{tabular}

${ }^{a}$ Significance level of 0.05 . Y - significant, N - not significant.

We checked the robustness of the results with the estimation methodology and built a logit model in order to define whether economic performance contributes to being an exporting company (it is a binary dependent variable). ${ }^{31}$ As independent variables we considered: productivity, ROA, ROE and ROS

${ }^{31}$ Formally, the logit model takes the form:

$$
\log \frac{P_{i}}{1-P_{i}}=\beta_{0}+\sum_{j=1}^{k} \beta_{j} x_{i j}+u_{i}
$$

where: $P_{\mathrm{i}}$ - the probability of occurrence of the i-th phenomenon, $\beta_{j}$-function parameter, $u_{i}-$ random component. The regression function takes the form:

$$
y_{i}^{*}=\beta_{0}+\sum_{j=1}^{k} \beta_{j} x_{i j}+u_{i}
$$

where: $y_{i}^{*}$ - independent variable (hidden variable).

The left side of equation (1) is the logarithm of the odds ratio, i.e., the ratio of probability (chance) that $y_{i}=1$ to the probability that $y_{i}=0$. If the odds ratio for a given variable is greater than 1 , it means that with the increase in the value of the explanatory variable, the probability of occurrence of the examined phenomenon increases. If the odds ratio is less than one, then as the value of this variable increases, the probability of occurrence of the studied phenomenon decreases. Using function (2), it is possible to classify objects into one of two groups. In our case, 
(except for ROE, the variables were statistically significant). In the case of productivity, the results are very similar to the previous ones. We did not confirm the hypothesis about there being a positive relation between productivity and exports, which means that an increase in average productivity was not followed by any changes in the probability of being an exporter. The correctness of the model classification is quite high and amounted to $73 \%$, but explains only $4.8 \%$ (R2) of changes in the dependent variable. Therefore, the model should be treated rather as symptomatic than as cause-and-effect.

\section{CONCLUSION}

In this article we investigated the relation between exports and economic performance and the extent of state ownership in the largest non-financial enterprises in Poland. The main conclusions of our research are as follows.

Firstly, the structure of the largest exporting Polish companies is dominated by state-owned enterprises. Among the 'Top 2000 companies', there were 31 exporting SOEs out of 44 SOEs, while $65.1 \%$ of private companies are exporters. In the structure of exports, large SOEs enjoy a dominating position. Among the top 25 exporters, 6 SOEs had as much as a $55 \%$ share in the total average export in 2013-2015. This could be explained by their longer experience and presence in the market (all of them were established in the socialist period) and by greater international experience. The largest exporting SOEs are active in the oil industry and mining sector. But when we estimated the propensity to export defined as a share of export in total turnover (without excise) of a company, SOEs experienced a substantially lower share in comparison to private companies (about 17 percentage points lower).

Secondly, according to the literature, we expected that exporters would have higher productivity than non-exporters. Our results are consistent with this only in the case of SOEs, though it is not statistically significant according to the tests. The main reason for the higher productivity of large SOEs could be that they enjoy a dominant position on the domestic oligopolistic market. This could be the source of their comparative advantage.

Thirdly, we compared the financial performance of non-exporters and exporters. As expected, the averages of all financial indicators show that exporters have statistically significantly higher ROA and ROS than non-exporters. When comparing the financial indicators of companies in terms of their ownership structure, we found that private companies performed better in the case of ROA and ROE than SOEs. This could be explained by the fact that private companies have a higher efficiency of property management and are expected to pay dividends by their shareholders.

a dependent variable $y=1$ is an exporting company (1,204 companies) and $y=0$ is a non-exporting company (642). 
Exports are one of the most important ways that a company can expand and experience economies of scope and scale. Our results confirm that exporting companies have significantly better financial performance. This could be either due to exports determining better firm performance or better performance contributing to exporting activities. However, our research does not prejudge that.

The analysis of the largest exporting SOEs in Poland could be developed in future research. The economic performance of SOEs could be analysed as a result of the market. It should also be compared in terms of different structures of ownership and patterns of corporate governance. Since the exports of the largest Polish SOEs constitute a substantial share in the total exports of the largest companies, an important driver of SOEs' economic performance and their ability to internationalize could be state's ownership policy and the corporate governance of SOEs. If a government aims to create national champions they must be export-oriented companies with high economic performance and good corporate governance.

\section{Katarzyna Szarzec}

Poznań University of Economics and Business

katarzyna.szarzec@ue.poznan.pl

https://orcid.org/0000-0002-7675-2239

Wanda Nowara

Statistical Office, Poznań

w.nowara@stat.gov.pl

https://orcid.org/0000-0002-9238-531X

Iwona Olejnik

Poznań University of Economics and Business

iwona.olejnik@ue.poznan.pl

https://orcid.org/0000-0002-2019-0580

Andersson, M., Lööf, H. (2009). Learning-by-exporting revisited: the role of intensity and persistence. Scandinavian Journal of Economics 111(4): 893-916.

Aw, B.Y., Chen, X., Roberts, M.J. (2001). Firm-level evidence on productivity differentials, turnover, and exports in Taiwanese manufacturing. Journal of Development Economics 66: $51-86$.

Bałtowski, M., Kozarzewski, P. (2016). Formal and real ownership structure of the Polish economy: state-owned versus state-controlled enterprises. Post-Communist Economies 28: 405419.

Bausch, A., Krist, M. (2007). The effect of context-related moderators on the internationalization-performance relationship: evidence from meta-analysis. Management International Review 47(3): 319-347.

Benito, G., Rygh, A., Lunnan, R. (2016). The benefits of internationalization for state-owned enterprises. Centre for Corporate Governance Research, Working Paper No. 1.

Brodzicki, T., Ciołek, D. (2016). Determinanty działalności eksportowej polskich firm produkcyjnych. Gospodarka Narodowa 2: 59-76.

Capar, N., Kotabe, M. (2003). The relationship between international diversification and performance in service firms. Journal of International Business Studies 34: 345-355. DOI:10.1057/ palgrave.jibs.8400036.

Cassiman, B., Golovko, E. (2007). Innovation and the export productivity link. IESE Business Scholl - University of Navarra Working Paper No. 688. 
Chen, H., Hsu, C.-W. (2010). Internationalization, resource allocation and firm performance. Industrial Marketing Management 29(7): 1103-1110. DOI:10.1016/j.indmarman.2009.10.001.

Cieślik, A., Michałek, J., Michałek, A. (2012). Determinanty działalności eksportowej polskich przedsiębiorstw. Gospodarka Narodowa 7/8: 67-84.

Cieślik, A., Michałek, J.J. (2017). Innovation forms and firm export performance: empirical evidence from ECA countries. Entrepreneurial Business and Economics Review 5(2). DOI:10.15678?EBER.2017.050205.

Contractor, F.J., Kumar, V., Kundu, S.K. (2007). Nature of the relationship between international expansion and performance: the case of emerging market firms. Journal of World Business 42(4): 401-417. DOI: 10.1016/j.jwb.2007.06.003.

Cuervo-Cazurra, A., Inkpen, A., Musacchio, A., Ramaswamy, K. (2014). Governments as owners: state-owned multinational companies. Journal of International Business Studies 45(8): 919942.

Delgado, M., Farinas, J., Ruano, S. (2002). Firm productivity and export markets: a non-parametric approach. Journal of International Economics 57: 397-422.

Doryń, W., Stachera, D. (2008). Wpływ internacjonalizacji na wyniki ekonomiczne największych polskich przedsiębiorstw przemysłowych. Gospodarka Narodowa 7/8: 67-84.

Elliot, R., Zhou, Y. (2013). State-Owned Enterprises, Exporting and Productivity in China: A Stochastic Dominance Approach. The World Economy 36(8): 1000-1028.

Estrin, S., Meyer, K., Nielsen, B., Nielsen, S. (2016). Home country institutions and the internationalization of state-owned enterprises: a cross-country analysis. Journal of World Business 51: 294-307.

Girma, S., Greenaway, D., Kneller, R. (2002). Does exporting lead to better performance? A microeconometric analysis of matched firms. GEP Research Paper 02/09. University of Nottingham.

Gorynia, M. (2007). Strategie zagranicznej ekspansji przedsiębiorstw. Warszawa: PWE.

Götz, M., Jankowska, B. (2018). Outward foreign direct investment by Polish state owned multinational enterprises: is 'stateness' an asset or a burden? Post-Communist Economies 30(2): 216-237. DOI:10.1080/14631377.2017.1361695.

Greenaway, D., Kneller, R. (2007). Firm heterogeneity, exporting, and foreign direct investment. Economic Journal 117(517): F134-F161.

GUS (2016). Działalność przedsiębiorstw niefinansowych w 2015 r. Warszawa: Główny Urząd Statystyczny.

Hagemejer, J. (2006). Czynniki wpływające na decyzje przedsiębiorstw o eksporcie. Analiza danych mikroekonomicznych. Bank i Kredyt 7: 30-43.

He, X., Eden, L., Hitt, M.A. (2016). The renaissance of state-owned multinationals. Thunderbird International Business Review 58(2): 117-129.

Helpman, E. (2006). Trade, FDI, and the organization of firms. Journal of Economic Literature 44: 589-630.

Kolasa, J., Hagemejer, M. (2008). Internationalization and economic performance of enterprises: evidence from firm-level data. NBP Working Paper No. 51.

Mariotti, S., Marzano, R. (2019). Varieties of capitalism and the internationalization of state-owned enterprises. Journal of International Business Studies 50(5): 669-691.

Melitz, M. (2003). The impact of trade on intra-industry reallocations and aggregate industry productivity. Econometrica 71(6): 1695-1725.

Mińska-Struzik, E. (2006). Produkcja międzynarodowa w świetle współczesnej teorii handlu międzynarodowego. Poznań: Wydawnictwo Akademii Ekonomicznej w Poznaniu.

Mińska-Struzik, E. (2014). Od eksportu do innowacji. Uczenie się przez eksport polskich przedsiębiorstw. Warszawa: Difin.

Musacchio, A., Lazzarini, S., Aguilera, R. (2015). New varieties of state capitalism: strategic and governance implications. Academy of Management Perspectives 29(1): 115-131.

Powell, D., Wagner, J. (2014). The exporter productivity premium along the productivity distribution: evidence from quantile regression with nonadditive firm fixed effects. Review of World Economics 150: 763-785.

Ramsey, J., Barakat, L., Cretoiu, S. (2012). Internationalization and its possible impact on subjective and objective performance: Evidence from Brazilian TNCs. Transnational Corporations 21(2): 21-46. 
Ratajczak-Mrozek, M. (2015). Czas w badaniach nad internacjonalizacją przedsiębiorstw. Gospodarka Narodowa 278(4): 49-67.

Riahi-Belkaoui, A. (1998). The effects of the degree of internationalization on firm performance. International Business Review 7: 315-325.

Rothenberg, T.J., Fisher, F.M., Tilanus, C.B. (1966). A note on estimation from a cauchy sample. Journal of the American Statistical Association 59: 460-463.

Ruigrok, W., Wagner, H. (2003). Internationalization and performance: an organizational learning perspective. Management International Review 43(1): 63-83.

Rzeczpospolita Top 2000 Polish Enterprises. Rzeczpospolita.

Singla, C., George, R. (2013). Internationalization and performance: a contextual analysis of Indian firms. Journal of Business Research 66: 2500-2506.

Szarzec, K., Nowara, W. (2017). The economic performance of state-owned enterprises in Central and Eastern Europe. Post-Communist Economies 29(3): 375-391.

Tallman, S., Li, J. (1996). Effects of international diversity and product diversity on the performance of multinationals firms. Academy of Management Journal 39(1), 179- 196.

Wagner, J. (2007). Exports and productivity: a survey of the evidence from firm level data. The World Economy 30(1): 60-82.

Wagner, J. (2012). International trade and firm performance: a survey of empirical studies since 2006. Review of World Economics 148(2): 235-267.

\section{EXPORTS AND THE ECONOMIC PERFORMANCE OF LARGE STATE-OWNED ENTERPRISES IN POLAND: EVIDENCE FROM FIRM-LEVEL DATA}

\section{Sum mary}

The aim of this paper is to investigate the relation between exports and the economic performance, and the extent of state ownership in the largest non-financial enterprises in Poland in 2011-2015. We address the following research questions: (i) What is the share of export companies in the group of the largest non-financial enterprises in Poland in terms of ownership structure (stateowned and privately-owned companies) and sectors? (ii) Are there differences in the economic performance of exporting companies compared to their non-exporting counterparts? Among the largest exporters, state-owned companies and companies from the manufacturing and mining sectors still dominate. Exporting state-owned enterprises have higher productivity than non-exporters, which could be caused by their dominant position on the domestic oligopolistic market. Exporting private-owned companies performed better in the case of ROA and ROE than exporting SOEs. This could be explained by the fact that private companies have a higher efficiency of property management and are expected to pay dividends by their shareholders.

Keywords: state-owned enterprises; export; economic performance; JEL codes: H82, L25, F14 